\title{
Pengaruh Mata Kuliah Pengukuran Besaran Listrik (PBL) Teori Terhadap Hasil Praktikum Pengukuran Besaran Listrik (PBL) Ditinjau dari Motivasi Belajar Mahasiswa IT - PLN
}

\author{
Dwi Anggaini ${ }^{1}$; Miftahul Fikri² Titi Ratnasari $^{3}$ \\ ${ }^{1,2,3}$ Insitut Teknologi PLN \\ 1 dwi_anggaini@itpln.ac.id
}

\begin{abstract}
Electrical Measurement is one of the courses in Electrical Engineering, which consists of theoretical and practical subjects. The system of taking practical courses should be implemented after taking theoretical courses or simultaneously in one semester. But in reality there are still students who take practical courses before taking theoretical courses, especially in the Electrical Measurement course. Based on the description above, the researcher would describe whether there is an influence of learning outcomes of Electrical Measurement Theoretical Courses on learning outcomes of Electrical Measurement Practical Courses. This research must be held to measure motivation to learn of students and learn the interaction between learning motivation and Electrical Measurement Practical Courses. This research was analyzed using two-way ANAVA (Two Way ANOVAI) with a $2 \times 2$ factorial design and further tests using Tukey Test. The result was there is an interaction between Electrical Measurement Theoretical Courses and student's learning motivation of their Electrical Measurement Practical Courses' results. This can be seen from 16.66 and Ft $=4.04$ at $\alpha=0.05$ with Fh> Ft means $H_{l}$ is accepted.
\end{abstract}

Keywords: Two Way ANOVA, $2 \times 2$ Factorial Design, Tukey Test, Validitas Test, Reliabel Test

\begin{abstract}
ABSTRAK
Pengukuran Besaran Listrik (PBL) adalah salah satu matakuliah yang ada di Teknik Elektro, yaitu terdiri dari mata kuliah teori dan mata kuliah praktek. Sistem pengambilan mata kuliah praktek sebaiknya dilaksanakan setelah mengambil mata kuliah teori atau secara bersamaan dalam satu semester. Namun pada kenyataanya masih ada mahasiswa yang mengambil mata kuliah praktek sebelum mengambil mata kuliah teori terutama pada mata kuliah Pengukuran Besaran Listrik (PBL). Berdasarkan uraian tersebut, peneliti akan mengemukakan apakah ada pengaruh Hasil Belajar Mata Kuliah PBL Teori terhadap Hasil Praktik Mata Kuliah PBL. Penelitian ini perlu diadakan untuk mengukur motivasi belajar mahasiswa serta mengetahui adanya interaksi antara motivasi belajar dengan praktikum PBL. Penelitian ini menggunakan ANAVA dua jalur (Two Way ANOVA) dengan design faktorial $2 \times 2$ dan uji lanjut dengan Uji Tukey. Hasil dari penelitian terdapat interaksi antara mata kuliah PBL dan motivasi belajar mahasiswa terhadap hasil praktikum PBL mahasiswa. Hal ini terlihat dari 16,66 dan $F_{t}=4,04$ pada $\alpha=0,05$ dengan $F_{h}>F_{t}$ berarti $H_{l}$ diterima.
\end{abstract}

Kata kunci: ANAVA dua jalur, Desain Faktorial 2x2, Uji Tukey, Uji Validitas, Uji Reliabilitas 


\section{Energi dan Kelistrikan: Jurnal Ilmiah}

Vol. 12, No. 2, Juli - Desember 2020, P-ISSN 1979-0783, E-ISSN 2655-5042

https://doi.org/10.33322/energi.v12i2.1083

\section{PENDAHULUAN}

Pendidikan di Indonesia terdiri atas Pendidikan dasar, pendidikan menengah, dan pendidikan tinggi menurut undang-undang Sistem Pendidikan Nasional Nomor 20 tahun 2003 pasal 1. Perguruan Tinggi adalah salah satu lembaga pendidikan, yaitu lembaga yang menyelenggarakan fungsi Pendidikan tertinggi. Berbeda dengan keluarga yang juga sama-sama menjalankan fungsi pendidikan, perguruan tinggi merupakan lembaga pendidikan formal, yaitu jalur lembaga pendidikan yang terstruktur dan berjenjang. Sementara keluarga adalah pendidikan in-formal yang tidak mengenal jenjang dan struktur pendidikan. Hal itu berarti bahwa secara dejure, perguruan tinggi merupakan salah satu lembaga yang secara khusus melaksanakan fungsi pendidikan bagi setiap masyarakat atau warga Negara [1]. Pengukuran Besaran Listrik adalah salah satu matakuliah yang ada di Teknik Elektro, yaitu terdiri dari mata kuliah teori dan mata kuliah praktek. Sistem pengambilan mata kuliah praktek sebaiknya dilaksanakan setelah mengambil mata kuliah teori atau secara bersamaan dalam satu semester. Namun pada kenyataanya masih ada mahasiswa yang mengambil mata kuliah praktek sebelum mengambil mata kuliah teori terutama pada mata kuliah Pengukuran Besaran Listrik (PBL). Berdasarkan uraian tersebut, peneliti akan mengemukakan apakah ada pengaruh Hasil Belajar Mata Kuliah PBL Teori terhadap Hasil Praktik Mata Kuliah PBL. Penelitian ini perlu diadakan untuk mengukur motivasi belajar mahasiswa dan mengetahui apakah ada interaksi antara motivasi belajar dengan praktikum PBL.

\section{METODE/PERANCANGAN PENELITIAN}

\subsection{Analisa Statistik}

Desain penelitian ini menggunakan penelitian eksperimen yaitu desain faktorial $2 \times 2$ [1] sebagai bentuk pemberian perlakuan.

Tabel 1. Design Penelitian Eksperimen

\begin{tabular}{|c|c|c|c|}
\hline $\begin{array}{c}\text { Motivasi Belajar } \\
\text { Mahasiswa } \\
(\text { B0) }\end{array}$ & \multicolumn{2}{|c|}{ Praktikum PBL (A0) } & \\
\cline { 2 - 4 } & $\begin{array}{c}\text { Sudah Mengambil Mata } \\
\text { Kuliah PBL }(\mathbf{A 1})\end{array}$ & $\begin{array}{c}\text { Belum Mengambil } \\
\text { Mata Kuliah PBL (A2) }\end{array}$ & $\sum \beta$ \\
\hline Tinggi $\left(\mathrm{B}_{1}\right)$ & $\mathrm{A}_{1} \mathrm{~B}_{1}$ & $\mathrm{~A}_{2} \mathrm{~B}_{1}$ & $\mathrm{~A}_{0} \mathrm{~B}_{1}$ \\
\hline Rendah $\left(\mathrm{B}_{2}\right)$ & $\mathrm{A}_{1} \mathrm{~B}_{2}$ & $\mathrm{~A}_{2} \mathrm{~B}_{2}$ & $\mathrm{~A}_{0} \mathrm{~B}_{2}$ \\
\hline$\sum \mathrm{k}$ & $\mathrm{A}_{1} \mathrm{~B}_{0}$ & $\mathrm{~A}_{2} \mathrm{~B}_{0}$ & $\mathrm{~A}_{0} \mathrm{~B}_{0}$ \\
\hline
\end{tabular}

Instrumen yang digunakan dalam penelitian ini adalah nilai praktikum Pengukuran Besaran Listrik (PBL) yang dilihat dari nilai mahasiswa yang sudah mengambil mata kuliah PBL teori atau belum mengambil mata kuliah PBL teori dan Instrumen motivasi belajar mahasiswa. Instrumen motivasi belajar mahasiswa terdiri dari instrumen Kuisioner yang berisi pertanyaan-pertanyaan tentang motivasi belajar dengan 4 (Empat pilihan Jawaban) [7]. Instrumen ini digunakan untuk menggolongkan mahasiswa dalam golongan mahasiswa dengan tingkat motivasi belajar tinggi dan mahasiswa dengan tingkat motivasi belajar rendah. Sebelum dilakukan penelitian, peneliti terlebih dahulu mengadakan uji validitas dan reliabilitas terhadap intrumen motivasi belajar yang akan digunakan dalam penelitian. Adapun dalam uji validitas peneliti menggunakan rumus korelasi Point Biserial.

$$
r_{b i s(i)}=\frac{\bar{X} i-\bar{X} t}{S_{t}} \sqrt{\frac{p_{i}}{q_{i}}}[12]
$$


Keterangan:

$$
\begin{array}{ll}
r_{b i s(i)} & =\text { Koefisien korelasi biserial skor butir dengan skor total } \\
\bar{X} i & =\text { Rata-rata skor total responden } \\
\bar{X} t & =\text { Rata-rata total semua responden } \\
S_{t} & =\text { Standar deviasi skor total semua responden } \\
p_{i} & =\text { Proporsi jawaban yang benar untuk butir soal nomor i } \\
q_{i} & =\text { Proporsi jawaban yang salah untuk butir soal nomor i }
\end{array}
$$

Dengan penentuan kevalidan suatu butir soal dengan membandingkan antara $r_{\text {butir }}$ dan $r_{\text {tabel }}$ dengan taraf signifikan 0,05. Jika $r_{\text {butir }}>r_{\text {tabel }}$ maka butir dianggap valid atau diterima dan jika $r_{\text {butir }} \leq$ $r_{\text {tabel }}$ maka butir dianggap tidak valid atau ditolak. Setelah melakukan uji validitas peneliti melakukan uji reliabilitas agar instrumen motivasi belajar dapat digeneralisir. Dalam uji reliabilitas, peneliti menggunakan rumus Kuder-Richard son 20 yaitu:

$$
r_{\Pi k}=\frac{k}{k-1}\left[1-\frac{\sum p q}{S_{t}{ }^{2}}\right] \text { [12] }
$$

Keterangan:

$$
\begin{array}{ll}
r_{k k} & =\text { Koefisien reliabilitas } \\
k & =\text { Banyak butir yang valid } \\
\Sigma p q & =\text { Jumlah varians skor butir } \\
S t^{2} & =\text { Varians skor total }
\end{array}
$$

\subsection{Diagram Alir Penelitian}

Kerangka kerja dalam penelitian ini adalah sebagai berikut:

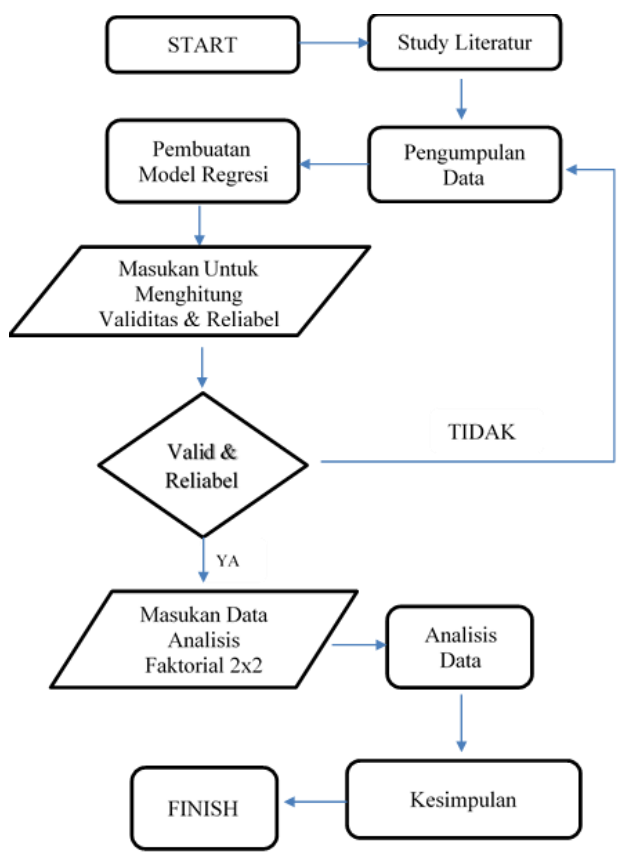

Gambar 1. Diagram Alir Penelitian 


\section{Energi dan Kelistrikan: Jurnal Ilmiah}

Vol. 12, No. 2, Juli - Desember 2020, P-ISSN 1979-0783, E-ISSN 2655-5042

https://doi.org/10.33322/energi.v12i2.1083

\section{HASIL DAN PEMBAHASAN}

Data yang diperoleh dalam penelitian dianalisis menggunakan ANAVA dua jalur (Two Way ANOVA) dengan design faktorial $2 \times 2$. Sebelum melakukan analisis data, terlebih dahulu melakukan uji persyaratan yaitu uji normalitas dan uji homogenitas terhadap dua kelompok tersebut. Adapaun dalam melakukan uji normalitas peneliti menggunakan taraf siginifikan $\alpha=0,05$ dengan kriteria jika $\mathrm{L}_{\text {tabel }}>\mathrm{L}_{\text {hitung }}$ maka data tersebut normal. Setelah mengadakan uji Normalitas, peneliti melakukan uji lanjutan yaitu melakukan uji homogenitas, yaitu dengan menggunakan uji bartlet. Jika nilai signifikan yang di dapat $>0,05$ maka sampel berasal dari data yang memiliki varians yang homogen.

Tabel 2. Deskripsi Data Hasil Penelitian

\begin{tabular}{|c|c|c|c|}
\hline \multirow{2}{*}{$\begin{array}{c}\text { Motivasi Belajar } \\
\text { (B0) }\end{array}$} & \multicolumn{2}{|c|}{ Praktikum PBL (A0) } & \\
\cline { 2 - 3 } & $\begin{array}{c}\text { Sudah Mengambil Mata } \\
\text { Kuliah PBL (A1) }\end{array}$ & $\begin{array}{c}\text { Belum Mengambil } \\
\text { Mata Kuliah PBL (A2) }\end{array}$ & $\sum \beta$ \\
\hline Tinggi (B1) & 89,46 & 69,69 & 79,58 \\
\hline Rendah (B2) & 66,85 & 58,62 & 62,73 \\
\hline$\sum \mathrm{k}$ & 78,15 & 64,15 & 71,15 \\
\hline
\end{tabular}

Hasil penelitian berdasarkan pengujian hipotesis menunjukan bahwa selurush hipotesis diterima, dengan demikian mata kuliah PBL teori berpengaruh terhadap hasil praktikum PBL dapat disimpulkan sebagai berikut:

1. Hasil praktikum PBL mahasiswa yang telah mengambil mata kuliah PBL teori lebih tinggi dari pada mahasiswa yang yang belum mengambil mata kuliah PBL teori.hal ini terlihat dari $F_{h}=142,04$ dan $F_{t}=4,04$ pada $\alpha=0,05$ dengan $F_{h}>F_{t}$ berarti $H_{1}$ diterima.

2. Terdapat interaksi antara mata kuliah PBL dan motivasi belajar mahasiswa terhadap hasil praktikum PBL mahasiswa. Hal ini terlihat dari $\mathrm{F}_{\mathrm{h}}=16,66$ dan $\mathrm{F}_{\mathrm{t}}=4,04$ pada $\alpha=0,05$ dengan $\mathrm{F}_{\mathrm{h}}>\mathrm{F}_{\mathrm{t}}$ berarti $\mathrm{H}_{1}$ diterima.

3. Mahasiswa yang memiliki tingkat motivasi belajar tinggi, hasil praktikum PBL mahasiswa yang telah mengambil matakuliah PBL teori lebih tinggi dari pada mahasiswa yang belum mengambil mata kuliah PBL teori.hal ini terlihat dari $\mathrm{F}_{\mathrm{h}}=14,02$ dan $\mathrm{F}_{\mathrm{t}}=4,04$ pada $\alpha=0,05$ dengan $\mathrm{F}_{\mathrm{h}}>\mathrm{F}_{\mathrm{t}}$ berarti $\mathrm{H}_{1}$ diterima.

4. Mahasiswa yang memiliki motivasi belajar rendah, hasil praktikum PBL mahasiswa yang telah mengambil mata kuliah PBL teori lebih tinggi dari pada hasil praktikum PBL mahasiswa yang belum mengambil mata kuliah PBL teori. $\mathrm{F}_{\mathrm{h}}=66,85$ dan $\mathrm{F}_{\mathrm{t}}=4,04$ pada $\alpha=0,05$ dengan $F_{h}>F_{t}$ berarti $H_{1}$ diterima.

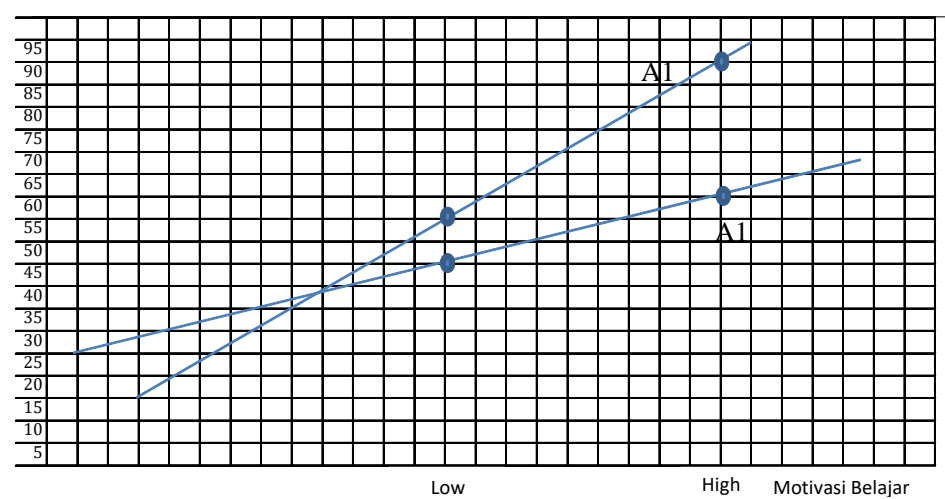

Gambar 2. Interaksi antara mata kuliah PBL teori dan motivasi belajar mahasiswa terhadap hasil praktikum PBL 
Jika terdapat interaksi antara motivasi belajar mahasiswa dengan hasil praktikum PBL mahasiswa, maka pengujian dilanjutkan dengan Uji Tukey[17].

Tabel 3. Rangkuman Uji Tukey

\begin{tabular}{|l|l|l|l|l|}
\hline No & \multicolumn{1}{|c|}{$\begin{array}{c}\text { Kelompok Yang } \\
\text { Dibandingkan }\end{array}$} & Qhitung & Qtabel & \multirow{2}{*}{ Kesimpulan } \\
\cline { 4 - 5 } & \multicolumn{1}{|c|}{} & & 0.05 & \\
\hline 1 & A1B1 dengan A2B1 & 14.02 & 4.15 & Signifikan \\
\hline 2 & A1B2 dengan A2B2 & 5.84 & 4.15 & Signifikan \\
\hline
\end{tabular}

Berdasarkan hasil uji lanjut tukey dapat disimpulkan sebagai berikut:

a. Dari hasil uji tukey diperoleh harga $\mathrm{Q}_{\text {hitung }}=14,02$ dan $\mathrm{Q}_{\text {tabel }}=4,15$ dengan demikian $\mathrm{Q}_{\text {hitung }}$ $>\mathrm{Q}_{\text {tabel }}=4,15$. Hal ini menunjukan bahwa terdapat perbedaan yang signifikan. Dengan demikian $\mathrm{H}_{0}$ ditolak dan $\mathrm{H}_{1}$ diterima maka dapat dinyatakan bahwa mahasiswa yang memiliki motivasi belajar tinggi dan telah mengambil mata kuliah PBL teori berbeda dengan mahasiswa yang memiliki motivasi belajar tinggi tetapi belum mengambil mata kuliah PBL teori. Dari hasil analisis diperoleh rata-rata nilai praktikum PBL, untuk mahasiswa yang memiliki motivasi belajar tinggi dan telah mengambil mata kuliah PBL teori sebesar 89.46 sedangkan nilai rata-rata praktikum PBL, untuk mahasiswa yang memiliki motivasi belajar tinggi tetapi belum mengambil mata kuliah PBL teori sebesar 69,69. Dengan demikian untuk mahasiswa yang memiliki motivasi belajar tinggi dan telah mengambil mata kuliah PBL teori hasil praktikumnya lebih tinggi dibandingkan dengan mahasiswa yang belum mengambil mata kuliah PBL teori.

b. Dari hasil uji tukey diperoleh harga $\mathrm{Q}_{\text {hitung }}=5,84$ dan $\mathrm{Q}_{\text {tabel }}=4,15$ dengan demikian $\mathrm{Q}_{\text {hitung }}$ $>\mathrm{Q}_{\text {tabel }}=4,15$. Hal ini menunjukan bahwa terdapat perbedaan yang signifikan. Dengan demikian $\mathrm{H}_{0}$ ditolak dan $\mathrm{H}_{1}$ diterima maka dapat dinyatakan bahwa mahasiswa yang memiliki motivasi belajar rendah dan telah mengambil mata kuliah PBL teori berbeda dengan mahasiswa yang memiliki motivasi belajar rendah tetapi belum mengambil mata kuliah PBL teori. Dari hasil analisis diperoleh rata-rata nilai praktikum PBL, untuk mahasiswa yang memiliki motivasi belajar rendah dan telah mengambil mata kuliah PBL teori sebesar 66,85 sedangkan nilai rata-rata praktikum PBL, untuk mahasiswa yang memiliki motivasi belajar rendah tetapi belum mengambil mata kuliah PBL teori sebesar 58,62 . Dengan demikian untuk mahasiswa yang memiliki motivasi belajar rendah dan telah mengambil mata kuliah PBL teori hasil praktikumnya lebih tinggi dibandingkan dengan mahasiswa yang belum mengambil mata kuliah PBL teori.

\section{KESIMPULAN DAN SARAN}

Kesimpulan dari hasil penelitian terdapat interaksi antara mata kuliah PBL teori dan motivasi belajar mahasiswa terhadap hasil praktikum PBL mahasiswa. Terdapat pengaruh yang signifikan antara mahasiswa yang telah mengambil mata kuliah PBL teori dan mahasiswa yang belum mengambil PBL teori terhadap hasil praktikum PBL mahasiswa.

Saran dalam penelitian ini, perlu adanya penyaringan melalui sistem bagi mahasiswa yang akan mengambil mata kuliah praktek PBL terlebih dahulu mengambil mata kuliah PBL.

\section{UCAPAN TERIMAKASIH}

Penulis mengucapkan terima kasih kepada Institut Teknologi PLN yang telah memberi dukungan moriil maupun materil. 


\section{Energi dan Kelistrikan: Jurnal Ilmiah}

Vol. 12, No. 2, Juli - Desember 2020, P-ISSN 1979-0783, E-ISSN 2655-5042

https://doi.org/10.33322/energi.v12i2.1083

\section{DAFTAR PUSTAKA}

[1] Alfian R, Putra AMP, "Uji Validitas dan Reliabilitas Kuesioner Medication Adherence Report Scale (MARS) Terhadap Pasien Diabetes Mellitus”, Jurnal Ilmiah Ibnu Sina, Vol. 2 No. 2, 2017

[2] Anggaini, D. Fikri, M. Setiawan D, "Pengaruh Evaluasi Tes Formatif Terhadap Hasil Belajar Matematika Ditinjau dari Tingkat Kemandirian Belajar Mahamahasiswa STT-PLN Jakarta Dengan Menggunakan Analisis Varian Anova”. Kilat, Vol. 7, No. 2, pp. 100-108, Okt. 2018, doi: https://doi.org/10.33322/kilat.v7i2.353.

[3] Anggaini, D. "Pengaruh Evaluasi Tes Formatif Terhadap Hasil Belajar Matematika Ditinjau Dari Tingkat Kemandirian Belajar". Jurnal Penelitian dan Penilaian Pendidikan, Vol 1, No. 1, $1-15$.

[4] Azhar N, Adri M, "Uji Validitas dan Reliabilitas Paket Multimedia Interaktif". IlmuKomputer.com

[5] Dewi, GAKRS, "Pengaruh Moralitas Individu dan Pengendalian Internal Pada Kecurangan Akuntansi (Studi Eksperimen pada Pemerintah Daerah Provinsi Bali)". Jurnal Ilmiah akuntansi, Vol. 1, No. 1, 2017.

[6] Dewi IK, Yunianto B, "Uji Efektivitas Sediaan Hand Sanitizer Kombinasi Ekstrak Daun Kemangi (Ocimum Sanctum L) Dan Ekstrak Kulit Jeruk Purut (Citrus Hystrix)", Jurnal Kebidanan dan Kesehatan Tradisional, Vol 1 No. 2, 2016

[7] Farhan, M. Retnawati, H, "Keefektifan PBL dan IBL ditinjau dari Prestasi Belajar, Kemampuan Representatsi Matematis dan Motivasi Belajar". Jurnal Riset Pendidikan Matematika, Vol. 1 No. 2, 2014.

[8] Hasti S, Emrizal E, Susilawati F, "Uji Aktivitas Antidiabetes Ekstrak N-heksana Daun Pucuk Merah (Syzygium Myrtifolium Walp.) Terhadap Mencit Putih Diabetes", Journal Farmasi Indonesia, Vol 13 No. 2, 2017

[9] Isnaini, M. Wardani, DK. Novian, L, "Pengaruh Kompetensi Dosen Dan Fasilitas Belajar Terhadap Kepuasan Mahamahasiswa Pendidikan Ekonomi FKIP UNS". Jurnal Pendidikan Bisnis dan Ekonomi, Vol. 1, No. 5, 2015.

[10] Irwan N, Sani RA, "Efek model pembelajaran kooperatif tipe group investigation dan teamwork skills terhadap hasil belajar fisika". Jurnal Pendidikan Fisika, Vol. 4 No. 1, 2015.

[11] IGAN WP, Sudjari S, Aurora H, "Uji Perbandingan Potensi Penambahan Ragi Tape dan Ragi Roti pada Larutan Gula sebagai Atraktan Nyamuk Aedes sp”, Majalah Kesehatan FKUB, 2016

[12] Prayitno, TA, "Pengembangan Petunjuk Praktikum Mikrobiologi Program Studi Pendidikan Biologi”. Jurnal Biota, Vol. 3, No. 1, 2017

[13] Prihartanta, W, "Teori-teori Motivasi”. Jurnal Adabiya, 2015

[14] Ramadan G, "Pengaruh metode pembelajaran dan motivasi belajar terhadap hasil belajar passing sepakbola", JUARA: Jurnal Olahraga, Vol. 2 No. 1, 2017

[15] Purnomo FH, Suryadi B, "Uji validitas konstruk pada instrumen religiusitas dengan metode Confirmatory Factor Analysis (CFA)”, Jurnal JP3I, Vol 6 No. 2, 2017

[16] Sari RT, "Uji Validitas Modul Pembelajaran Biologi Pada Materi Sistem Reproduksi Manusia Melalui Pendekatan Konstruktivisme Untuk Kelas IX SMP”, Scientiae Educatia: Jurnal Pendidikan Sains, Vol. 6 No. 1, 2017, doi: 10.24235/sc.educatia.v6i1.1296

[17] Suparman, AR, "Pengaruh Strategi Pembelajaran Dan Gaya Kognitif Terhadap Hasil Belajar Kognitif Peserta Didik Kelas Xi Ipa2 Sma Negeri 2 Sungguminasa”. Jurnal Nalar Pendidikan, Vol. 3, No. 1, 2015. 
[18] Sudibyo, E. Jatmiko, B. Widodo, W, "Pengembangan Instrumen Motivasi Belajar Fisika: Angket”. Jurnal Penelitian Pendidikan IPA, Vol. 1, No. 1, 2016.

[19] Surayya L, Subagia IW, Tika IN, "Pengaruh model pembelajaran think pair share terhadap hasil belajar IPA ditinjau dari keterampilan berpikir kritis siswa". Jurnal Pendidikan dan Pembelajaran IPA Indonesia, Vol 4 No. 1, 2014.

[20] Wati NR, Sembodo DRJ, "Uji Efektifitas Herbisida Atrazin, Mesotrion, dan Campuran Atrazin+ Mesotrion terhadap Beberapa Jenis Gulma", Jurnal Penelitian Pertanian Terapan, Vol 15 No, 1, 2017

[21] Yusup F. "Uji validitas dan reliabilitas instrumen penelitian kuantitatif" Jurnal Ilmiah Kependidikan, Vol. 7 No. 1, 2018, doi: http://dx.doi.org/10.18592/tarbiyah.v7i1.2100 